\title{
RADIOCARBON CHRONOLOGY OF THE HOLOCENE DEAD SEA: ATTEMPTING A REGIONAL CORRELATION
}

\author{
Amos Frumkin ${ }^{1,2} \bullet$ Galit Kadan $^{3} \bullet$ Yehouda Enzel $^{1,4} \bullet$ Yehuda Eyal $^{3}$ \\ ABSTRACT. Holocene sedimentary and geomorphic sequences from the Dead Sea region, Israel, are compared by correla- \\ tion of more than 50 radiocarbon dates. The ${ }^{14} \mathrm{C}$ dates provided the chronological basis that enabled us to detect basin-scale \\ events that are hard to ascertain in single-site records. This paper is the first attempt to compare different Holocene records \\ from several sites along the Dead Sea, based on their chrono-stratigraphy. Included is the first publication of the paleoclimatic \\ record of the Nahal Darga ephemeral stream valley. Such a regional compilation is needed, because only the integration and \\ comparative evaluation of several records can produce a reliable climatic history by establishing the height of former Dead \\ Sea levels that may be complicated by tectonics and the rise of Mount Sedom. A relatively high level of the Holocene Dead \\ Sea occurred during the mid-Holocene around $4400 \mathrm{BP}$ or about $3000 \mathrm{cal}$ BCE after calibration. The lake level fell sharply \\ around $4000 \mathrm{BP}$, i.e. $2500 \mathrm{cal} \mathrm{BCE}$, and later fluctuated close to early 20 th century levels. The ${ }^{14} \mathrm{C}$-based correlation is also \\ used to estimate the rising rates of the Mount Sedom salt diapir that are apparently smaller than $10 \mathrm{~mm}$ per year.
}

\section{INTRODUCTION}

The Dead Sea is a Holocene lake with a catchment area of some $40,000 \mathrm{~km}^{2}$, including the Jordan River catchment system (Figure 1). Being a terminal lake with historical documentation of about $4000 \mathrm{yr}$ (Neev and Emery 1967; Frumkin 1997), its hydrologic history is important for past geologic, paleoclimatic, and historic reconstruction.

The Dead Sea is located within an extremely arid environment with annual precipitation of 50$100 \mathrm{~mm}$, but the northwestern part of its catchment has a semi-arid to sub-humid climate. Most of its water is, therefore, derived from Mediterranean environment rainfall at the wetter northern part of its catchment. In addition, the Dead Sea serves as a base level for intermittent streams (wadis) with catchments in the arid to semi-arid regions, including the Judean Desert, the western part of Jordan, and a large portion of the Negev Desert. The water mass of the Dead Sea contains mostly Mg-Ca-chloridic brine close to saturation with respect to salt and gypsum (Neev and Emery 1967; Stiller et al. 1997). The water has a wide range of inorganic radiocarbon composition (Stiller et al. 1988; Talma et al. 1997). Runoff water often formed a less saline layer at the top of the water column. This stratification of the lake water continued until 1979 (Steinhorn et al. 1979), when recent human impact caused an overturn of the lake water and holomictic (unstratified) conditions. Meromictic (stratified) conditions reoccurred shortly from 1992 to 1995 following the 1992 and 1993 wet years (Anati et al. 1995). Alternations between holomictic and meromictic structure have also occurred naturally in the past (Stiller and Chung 1984) inducing changes in the bottom lake sediments-conditions for salt deposition may develop during unstratified stages indicating low precipitation/evaporation ratio, while marl is a common deposit during stratified conditions resulting from high precipitation/evaporation ratio (Ben-Avraham et al. 1999). The marl typically contains thin layers of aragonite, calcite, detrital silt, and clay (Elazari-Volcani 1943; Neev and Emery 1967).

The detrital component of the sediments is mostly clay at the center of the lake, but grain size and quantity of clastic sediments increase towards the margins of the lake, especially near fan-deltas where gravel is transported by streams into the lake or deposited close to its shore (e.g. Manspeizer

\footnotetext{
${ }^{1}$ Department of Geography, The Hebrew University of Jerusalem, 91905, Israel

${ }^{2}$ Corresponding author. Email: msamos@mscc.huji.ac.il

${ }^{3}$ Department of Geology and Environmental Sciences, Ben Gurion University of the Negev, Beer-Sheva 84105, Israel

${ }^{4}$ Institute of Earth Science, The Hebrew University of Jerusalem, 91904, Israel
} 
1985; Kadan 1997). The shore environment is characterized by interfingering relations between fluvial, lacustrine, and shore deposits. Grain and clast size changes dramatically within each stratigraphic section, according to lake level and the lake-shore position relative to the studied site (e.g. Enzel et al. 2000). Clay and silt sediments located further onshore commonly indicate higher lake levels, allowing for low-energy underwater deposition. Allogenic supply of sediment may also vary according to runoff regime in the catchment of the transporting fluvial system that is climatically controlled-larger portion of the fine-grains is probably associated with wetter conditions in the catchment (Bull 1991). The climatic conditions and associated grain size distribution may vary between neighboring catchments draining into the Dead Sea from the west. Near-shore sections suffer more often from unconformities associated with non-deposition and erosion during low levels of the lake.

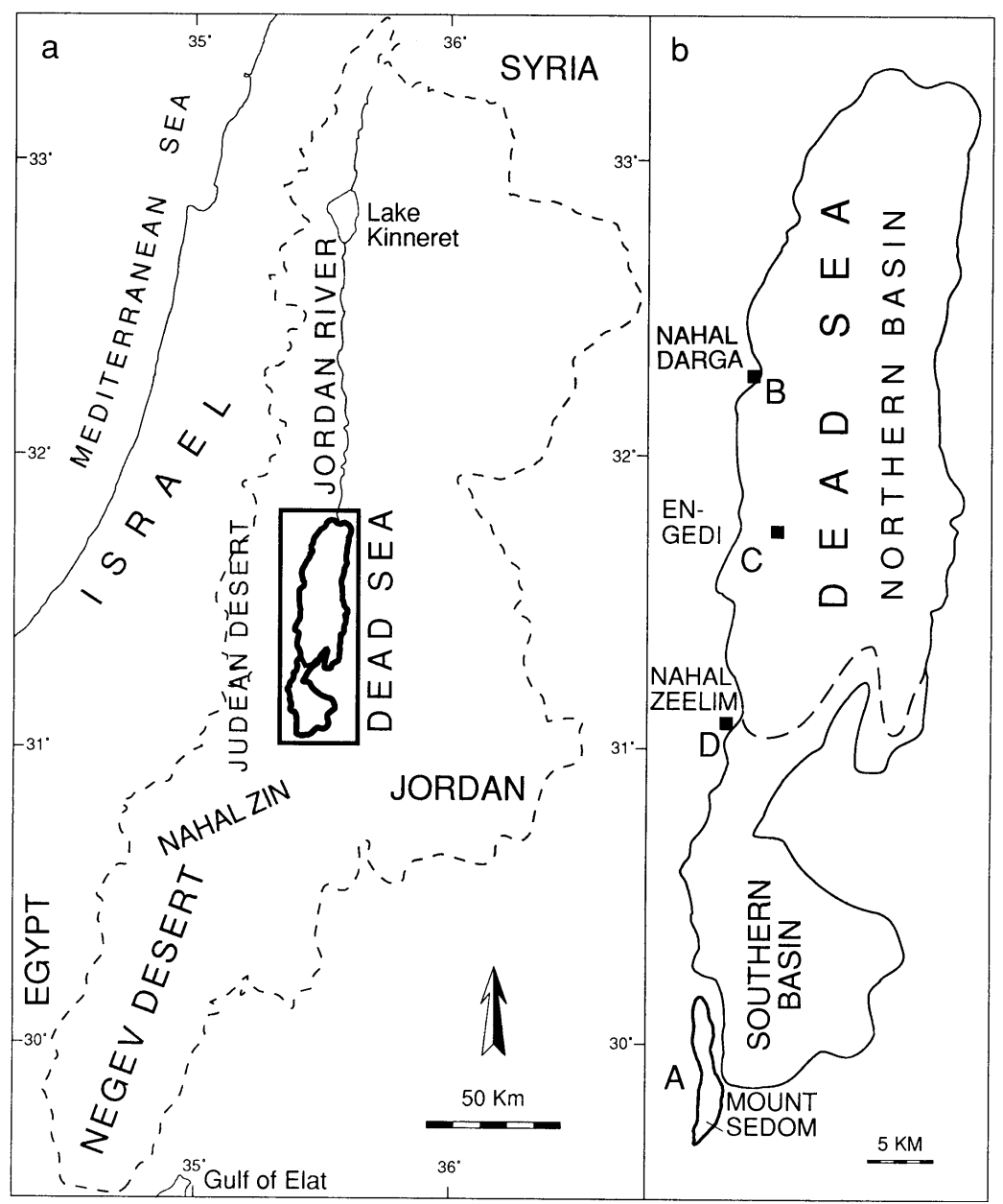

Figure 1 Catchment of the Dead Sea (a) and location of the Dead Sea records (b): (A) Mount Sedom caves (Frumkin et al. 1991); (B) Nahal Darga (Enzel et al. 2000; Kadan 1997); (C) Core drilled near En Gedi (Ben-Avraham et al. 1999; Heim et al. 1997); (D) Core drilled in Nahal Zeelim fan-delta (Yechieli et al. 1993) 
Some of the best 2- to 3-dimensional exposures of Holocene deposits are located in fan deltas, as they are often dissected by the downcutting streams that follow the present falling level of the lake (Kadan 1997; Ken-Tor et al. 1998, and this volume; Enzel et al. 2000; Bowman et al. 2000 and this volume). Such outcrops often allow the exact determination of the shoreline position at a specific stratigraphic unit by following the changes and shoreline indicators, such as beach ridges (Otvos 2000). Identification of such features allows using the lake level itself as a correlation tool between various sites along the shoreline (Bartov et al. in press). Terraces and caves along the escarpment border of the lake often preserve a good record of the shoreline too (Klein 1982; Frumkin 2001). Excellent preservation of sediment and organic material can be found in underground cave passages. The salt caves of Mount Sedom provide a good record for high lake levels, but not for levels below about $-390 \mathrm{~m}$ - the base of Mount Sedom (Frumkin et al. 1991). As the caves are formed in an actively rising salt diapir, the lake level cannot be independently determined from these caves unless the diapir uplift rate is known.

Borehole data, collected by several researchers (e.g. Yechieli et al. 1993; Neev and Emery 1995; Heim et al. 1997; Migowski et al. 1998), may not always be so well understood in terms of sedimentation and truncation history, because they lack the horizontal lateral dimension. However, boreholes can be drilled in most places where outcrops and geomorphology cannot be used. In the deeper lacustrine environment boreholes may supply more complete records than subaerial exposures.

The overall complex association of sediments and shore morphology challenges the attempts to correlate the evidence in various locations using the methods mentioned above, although recently Machlus et al. (2000) showed their potential. ${ }^{14} \mathrm{C}$ dating has been used successfully in the past as a correlation tool in other lakes (e.g. Butzer and Issac 1972; McClure 1976; Street and Grove 1979; Roberts 1982), but such attempts have hardly been made for the Dead Sea. We attempt a chronological correlation based on ${ }^{14} \mathrm{C}$-dated sequences along the western side of the Dead Sea. These ${ }^{14} \mathrm{C}$ ages allow us to detect basin scale events. In this paper we use previously published sequences from several sites dated in several laboratories to establish the chronological framework of the region during the Holocene. We show the possible use of these correlations for paleoclimate reconstruction and estimation of Mount Sedom uplift rate during the Holocene.

\section{${ }^{14} \mathrm{C}$ CHRONOLOGY}

To allow simple correlation we use conventional uncalibrated dates (unless indicated otherwise), thus, the precision of our correlation is limited by the probability distribution of calibrated ages, especially, when it involves several ranges of possible age.

We use ages from sequences previously shown to be internally consistent; each sequence is dated by at least four ${ }^{14} \mathrm{C}$ dates of organic matter, all in correct stratigraphic order within $2 \sigma$ confidence level of the ${ }^{14} \mathrm{C}$ ages. We omitted dated carbonates, in which the autogenic carbonate was not carefully separated from allogenic detrital carbonates with low ${ }^{14} \mathrm{C}$ content resulting in large dating errors (Neev and Emery 1995). This problem has been avoided in the study of the Lisan, the predecessor of the Dead Sea, by using only autogenic aragonite (Schramm et al. 2000).

Within the non-dated parts of the records the adopted age model is based on the assumption that constant average deposition rate occurred between adjacent ${ }^{14} \mathrm{C}$ ages, provided that the lithology does not change. Rates of deposition are assumed to change across major lithological boundaries (BenAvraham et al. 1999) so the rates are calculated separately for each lithozone. 
Our correlation is based upon the major dated events in the studied proxies represented by outstanding lithological changes such as between salt and marl or between gravel and lacustrine silt. We ignore the observed smaller changes assumed not to represent major environmental changes, although we admit that this assumption might be wrong. A common regional environmental control of the Dead Sea is suggested only in cases where a similar type of event (e.g. change from high to low lake level) occurs concurrently in a few records. The correlation takes into account the appropriate confidence level of the ages. Apart from the laboratory estimate of the dating error, we also consider the reliability of the published ages in terms of the shape of the ${ }^{14} \mathrm{C}$ calibration curve in the relevant period and the type of material used for dating. We assume larger error margins for materials that might have experienced considerable delay between the plant's consumption of atmospheric ${ }^{14} \mathrm{C}$ and the deposition within the studied site, although Ken-Tor et al. (this volume) show that this delay is probably very short. Some undated parts of the discussed records were added to Figure 2 (dotted lines) to complement the discussion that predominantly relies on the dated sequences.

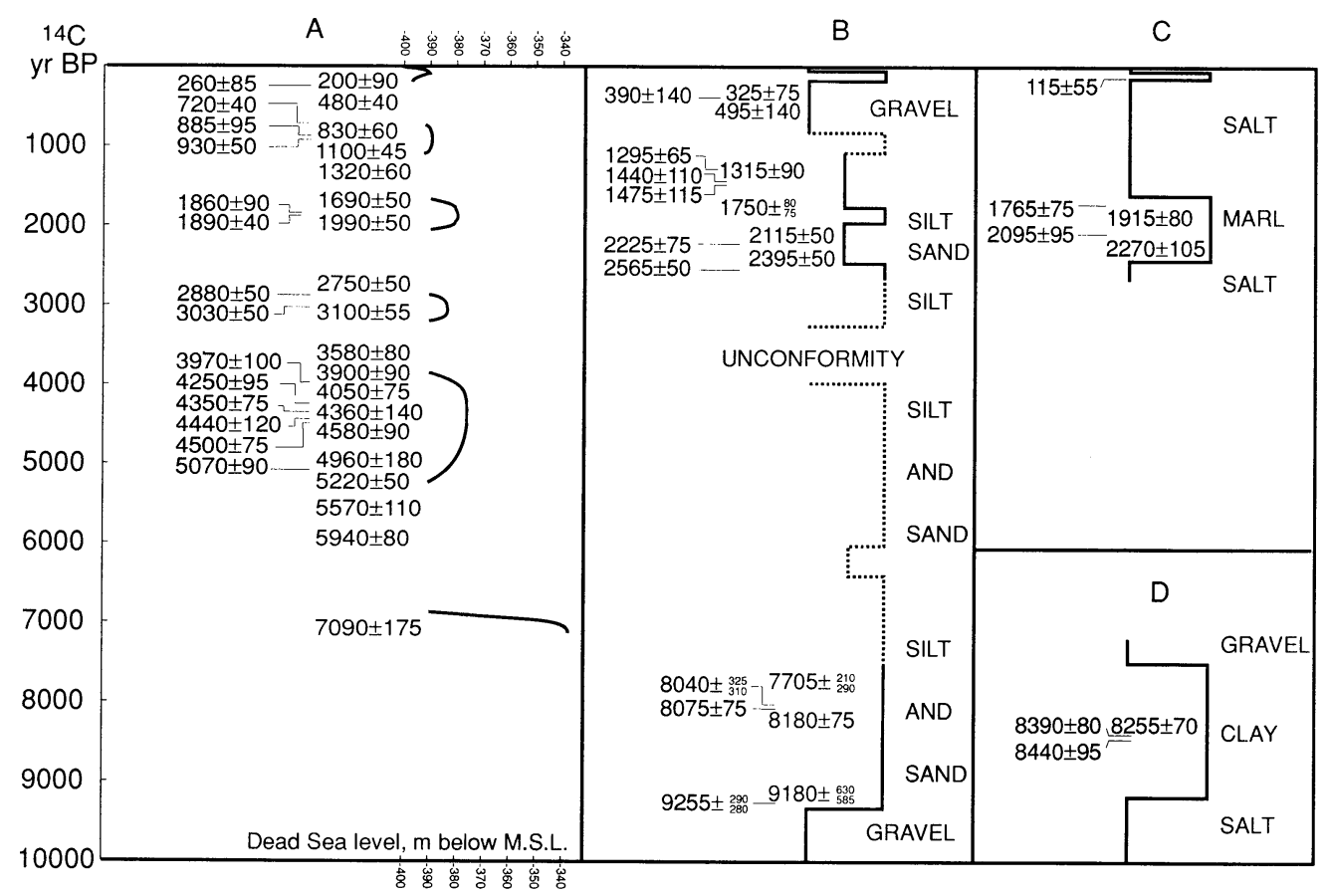

Figure $2{ }^{14} \mathrm{C}$ chronology of four Dead Sea records: (A) Dead Sea level according to Mount Sedom caves assuming diapir rising rate of $6 \mathrm{~mm} / \mathrm{yr}$ (Frumkin 1997; Frumkin et al. 1994); (B) Nahal Darga fan-delta outcrop (Enzel et al. 2000; Kadan 1997), dotted lines indicate non-dated stratigraphic changes in the record; (C) Core drilled in the northern basin near En Gedi (Ben-Avraham et al. 1999; Heim et al. 1997); (D) Core drilled in Nahal Zeelim fandelta (Yechieli et al. 1993)

\section{REGIONAL CORRELATIONS}

\section{End of Pleistocene Salt Deposition}

The latest Pleistocene ends with extensive salt deposition known from several boreholes along the Dead Sea shore (Yechieli et al. 1993; Migowski et al. 1998; Yechieli 2000). The salt deposition event is supposed to be associated with the drying of late Pleistocene Lake Lisan (Neev and Emery 1967; 
Begin et al. 1985; Druckman et al. 1987) but it is not well dated. A single ${ }^{14} \mathrm{C}$ age of $11,315 \pm 80 \mathrm{BP}$ (ETH-4982) (Yechieli et al. 1993) from just below the base of a salt unit indicates that this dry event may be associated with the Younger Dryas (e.g. Kudrass et al. 1991; Roberts et al. 1993; Taylor et al. 1997).

\section{Early Holocene Rising Lake}

Three ages within the clay overlying the salt in the same Nahal Zeelim core fall in a short time range from $8255 \pm 70$ (RT-947) to $8440 \pm 95$ BP (ETH-6156) (Figure 2D). These ages are corroborated by a similar preliminary age of plant relicts overlying the salt in En Gedi (Migowski et al. 1998). This lower Holocene time range correlates to a lacustrine deposit in Nahal Darga (Enzel et al. 2000; Kadan 1997), the lowermost age of which is $9255+290-280$ BP (A-7952), followed by $9180+630$ -585 BP (A-7953) (Figure 2B). This is a silt deposit overlying some gravel layers that lack any matrix. Altogether, the early Holocene event of rising lake level from its low stage and initiation of deposition of fine lacustrine sediment correlates well through the known dated sequences. This event commenced probably around 9000-9500 BP or somewhat earlier.

The end of this early Holocene wet event is less well dated. In Nahal Zeelim this falling lake event is indicated by a depositional shift from clay to gravel, occurring about $2 \mathrm{~m}$ above the uppermost age, $8255 \pm 70$ BP (RT-947) (Yechieli et al. 1993). Goodfriend et al. (1986) reported a high lake level of $-280 \mathrm{~m}$ which precipitated salt over land snails dated to $6660 \pm 400 \mathrm{BP}$ (RT-725). The receding lake has exposed the top of the southern Mount Sedom to salt karst development (Frumkin 1996a), as indicated by the earliest cave in the mountain dated to $7090 \pm 75$ BP (RT-886H) (Frumkin et al. 1991). This is followed by downcutting in the cave indicating rapid fall of the lake level.

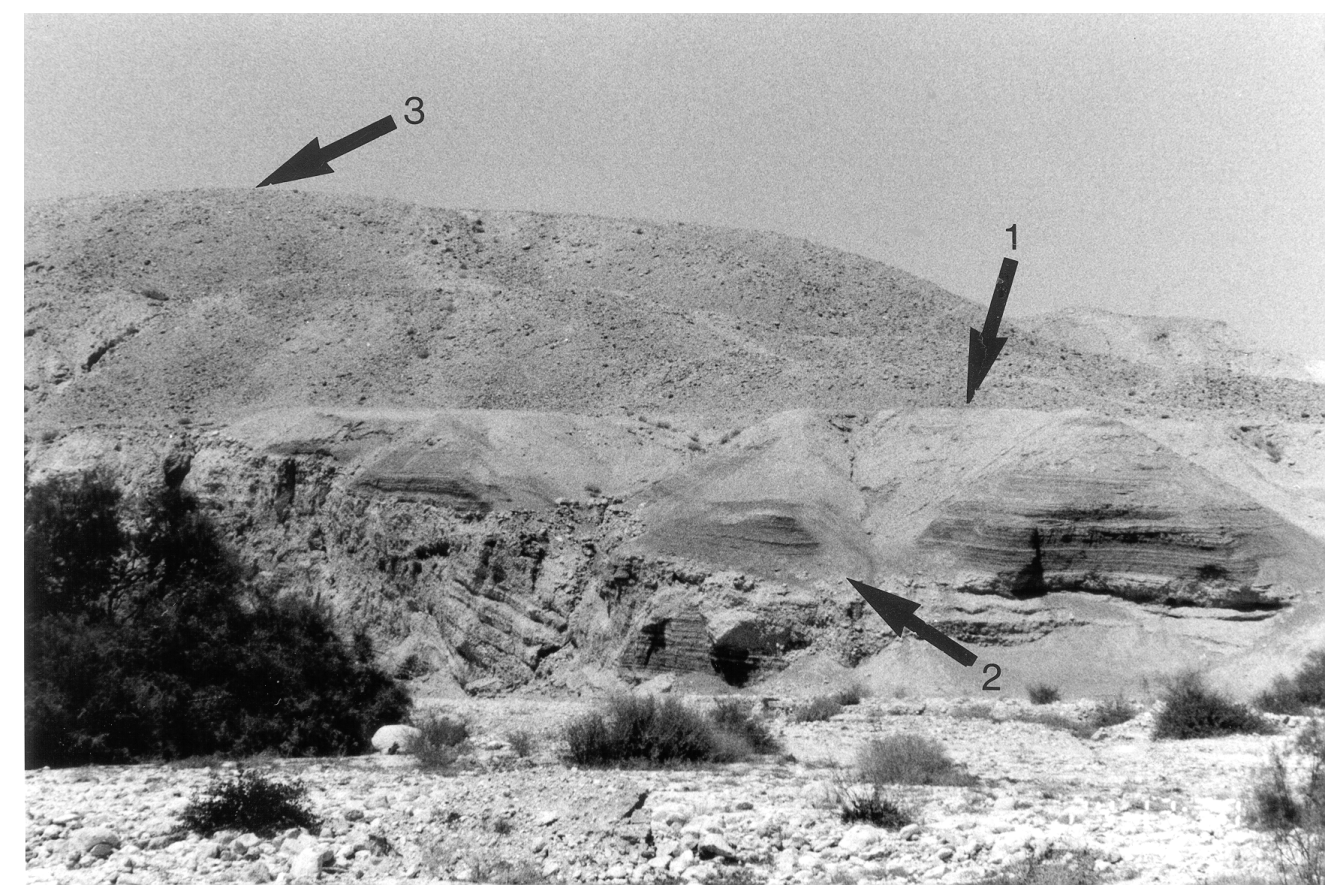

Figure 3 The main terraces at the northern wall of Nahal Darga, with active channel at the bottom: (1) Top of midHolocene terrace, with a beach ridge at a level of about $-370 \mathrm{~m}$. (2) Contact between early Holocene (?) and midHolocene layers; (3) Late Pleistocene fan-delta terrace 


\section{Mid-Holocene High Lake Level}

Mount Sedom caves record suggests that the wettest event of the last $7000 \mathrm{yr}$ occurred during the Mid-Holocene indicated by wide and high cave passages (Frumkin et al. 1994). Twelve ${ }^{14} \mathrm{C}$ ages from this stage in Mount Sedom range between $5220 \pm 50$ (RT-1205) and $3900 \pm 90$ BP (RT-810B) (Figure 2A). In Nahal Darga this phase is most probably represented by a few-meter-thick layer of lacustrine silt yet undated directly (Kadan 1997). Support for this assumption is the westward termination of this unit with a beach ridge at a level of about $-370 \mathrm{~m}$ (Figure 3, previous page) that is higher than any shore deposits since (Kadan 1997; see also BenDavid-Novak 1998). A level higher than about $-370 \mathrm{~m}$ at this stage, suggested by the distribution of oak twigs in Mount Sedom caves (Frumkin et al. 1991), is not supported by other records.

\section{Rapid Lake Level Fall at the End of Mid-Holocene High Stage}

Rapid downcutting of narrow canyon passages is documented in Mount Sedom caves around 3580 $\pm 80 \mathrm{BP}$ (RT-810D) indicating rapid fall of the Dead Sea level (Frumkin et al. 1994). A major unconformity in Nahal Darga was attributed to this event (Kadan 1997), although direct dating for this site is not available. A gypsum layer in En Gedi just beneath the age of $3680 \pm 40$ (Migowski et al. 1998) probably reflects the same lake falling event.

\section{Small Amplitude Rising Levels of Late Holocene}

A somewhat higher level event is documented in Mount Sedom by two ages: $3100 \pm 55$ (RT-982G) and $3030 \pm 50$ BP (RT-982E) (Figure 4) (Frumkin et al. 1994). Two other Sedom ages, $2880 \pm 50$ (RT-943B) and 2750 \pm 50 (RT-943A), may also be associated with this event (Figure 2A). This event is apparently recorded as a lacustrine silt layer embedded between gravel and sand units above a major unconformity in Nahal Darga (Kadan 1997; Enzel et al. 2000) dated at the same age of 2565 \pm 50 BP (A-7948) (Figure 2B). This correlation still demands corroboration.

The next relatively higher lake level recorded in Mount Sedom is dated by four ${ }^{14} \mathrm{C}$ ages ranging from $1990 \pm 50$ BP (RT-982F) to $1690 \pm 50$ BP (RT-1235). In Nahal Darga the age of a lacustrine silt layer overlying sand and overlaid by gravel is constrained between $2115 \pm 50 \mathrm{BP}$ (A-7949) and $1750+80-75$ BP (A-8358) (Kadan 1997; Enzel et al. 2000). Within the deeper part of the Dead Sea northern basin this event is expressed by laminated marls sandwiched between salt layers (Heim et al. 1997). Four ${ }^{14} \mathrm{C}$ ages within this marl unit range from $2270 \pm 105$ (ETH-15434) to $1765 \pm 75 \mathrm{BP}$ (ETH-15432) (Figure 2C).

Holocene stratigraphy observed in seismic reflection profiles across other parts of the northern Dead Sea basin can be interpreted similarly (Ben-Avraham et al. 1999). The documented sediment sequence indicates changes in the salinity of the upper water mass associated with lake level fluctuations. Both are controlled by evaporation/runoff ratio as corroborated by palynological data from the same core (Heim et al. 1997).

\section{9th-20th Century}

The latest high level event that is common in the various records has occurred during the late 19th to mid-20th century (Frumkin 1997; Kadan 1997; Ben-Avraham et al. 1999). This period is well documented by historical evidence and direct measurements of rising lake up to about $-390 \mathrm{~m}$ (Klein 1965). Laminated marl was the main deposit of the Dead Sea until the overturn of its water column on 1979 CE. The marl of this last high level event is exposed today along most of the Dead 


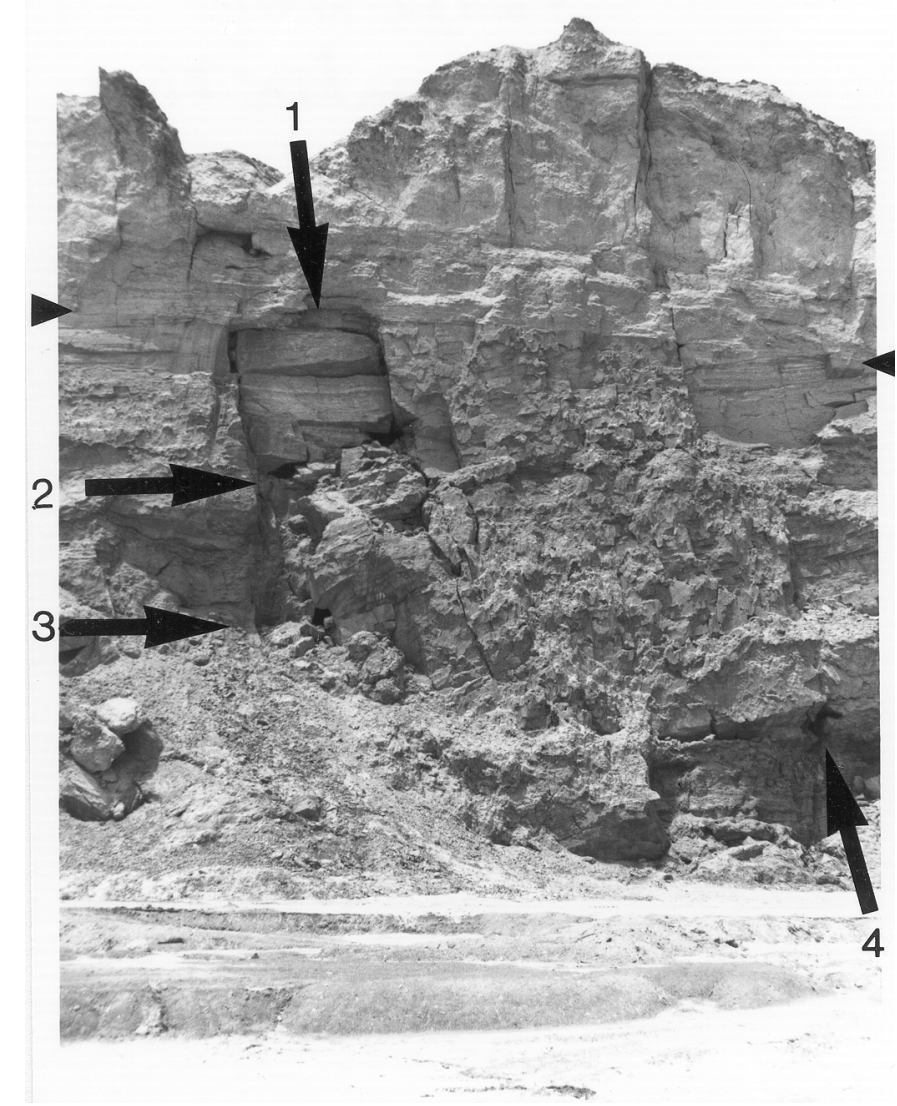

Figure 4 The north-eastern face of Mount Sedom, with four-level outlets (indicated by numbers) of Mishqafaim Cave: Level 1 is the uppermost outlet dated by two radiocarbon ages to $3100 \pm 55$ and $3030 \pm 50 \mathrm{BP}$. The passage is close to the top of the salt (indicated by triangles), just under the caprock; Level 2 is lower, with ages ranging from $1990 \pm 50$ to $1690 \pm 50$ $\mathrm{BP}$; Level 3 is dated to $930 \pm 50$ and $885 \pm 95 \mathrm{BP}$; Level 4 is active today

sea shore. The Dead Sea reached the base of Mount Sedom at this stage and the outlets of most caves are graded to about $-390 \mathrm{~m}$.

Halite has been a major deposit of the Dead Sea since 1982/3 (Anati et al. 1987; Gavrieli 1997; Stiller et al. 1997). The shift to halite deposition is attributed to human use of the water from the catchment and evaporating Dead Sea water for potash extraction. Therefore, during the second half of the 20th century the Dead Sea level ceased serving as a proxy for climatic change.

\section{High Runoff Events in the Desert}

Events that are not recorded by several Dead Sea proxies may be of local importance or may relate to the southern arid part of the Dead Sea catchment. A possible example may be the period of highintensity runoff dated to about $1100-700 \mathrm{BP}$ by five ${ }^{14} \mathrm{C}$ ages from Mount Sedom where cave passages became wide (Frumkin et al. 1998), two ages in Nahal Zin (Greenbaum et al. 2000), and apparently also at Nahal Darga (Kadan 1997). During this period Nahal Zin had the highest flood 
frequency during the last $2000 \mathrm{yr}$ (Greenbaum et al. 2000). The absence of this event from the deep Dead Sea record may indicate an increase of local storms in southern Israel produced by active Red Sea Trough that is responsible for most high-intensity rainfall and flood events at the southern Negev Desert today (Kahana 1999). Such an increase of floods may be insignificant to the total amount of water in the Dead Sea, which receives most of its water input from the Mediterranean westerlies.

\section{IMPLICATIONS FOR THE RISING RATE OF MOUNT SEDOM DIAPIR}

Mount Sedom salt diapir is rising during the Holocene compared with its surroundings and the Dead Sea shore (Zak 1967). The uplift rate may change with time. Past estimations of average rising rates of Mount Sedom diapir were based on Lisan deposits deformation (Zak 1967), direct measurement (Frumkin 1992), and cave levels (Frumkin 1996b). Lacking a stable point of reference, only relative average values are obtained from these estimates.

Absolute average values of uplift rate may be obtained if a certain Dead Sea level indicator can be identified in both Mount Sedom and in comparatively stable shore outside the diapir. Reliable correlation between such benchmarks can be established based on ${ }^{14} \mathrm{C}$-dated cave levels of Mount Sedom to ${ }^{14} \mathrm{C}$-dated shorelines such as found in Nahal Darga. A relevant data point is a lacustrine silt

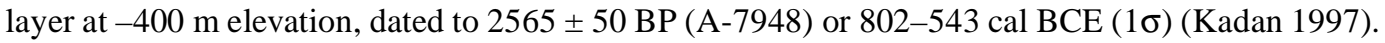
Assuming only minor tectonic movement of this layer since deposition, the $-400 \mathrm{~m}$ elevation of the layer must be the minimum Dead Sea level for the deposition period. A cave level in Mount Sedom, today at $-365 \mathrm{~m}$, has two ${ }^{14} \mathrm{C}$ ages: $3100 \pm 55$ (RT-982G) and $3030 \pm 50 \mathrm{BP}$ (RT-982E) or 1436$1312 \mathrm{cal} \mathrm{BCE}$ and $1393-1258 \mathrm{cal}$ BCE $(1 \sigma)$, respectively (Frumkin et al. 1994). The general similarity of the chronology of lake levels derived from Mount Sedom and Nahal Darga may suggest that the high level event recorded in Mount Sedom at about 3030-3100 BP could have continued until close to about $2565 \mathrm{BP}$ as recorded in Nahal Darga. If additional dating will show that the two indeed belong to the same high lake level event, then a diapir uplift rate may be inferred. If the cave passage developed when Dead Sea level was higher than -400 and assuming an average calendar age of 1350 BCE for the cave (Frumkin et al. 1991), then the associated cave level has been rising up to $35 \mathrm{~m}$ during the last $3350 \mathrm{yr}$, yielding an average diapir rising rate less than $10.5 \mathrm{~mm} / \mathrm{yr}$. This range is in agreement with previous estimated rates relative to base level (Frumkin 1996b). If we assume that the Dead Sea level was not much higher than the $-400 \mathrm{~m}$ reference level during this period (Kadan 1997), then the diapir uplift rate would be only slightly smaller than the calculated $10.5 \mathrm{~mm} / \mathrm{yr}$ value. This is in agreement with the $9 \pm 5 \mathrm{~mm} / \mathrm{yr}$ measured for recent years (Frumkin 1992) and the maximum mean rate of 6-7 mm/yr estimated for the Holocene by evaluating all dated cave levels (Frumkin 1996b).

The above calculation is approximate, because it is based on near shore lake deposits of unknown initial depth below water level. To arrive at a more accurate estimate of the diapir rising rate we should rely on more dated lake-related benchmarks, such as beach ridges of the Dead Sea (Kadan 1997). Such an estimate may be derived from the mid-Holocene beach ridge whose maximum elevation at Nahal Darga is about $-370 \mathrm{~m}$. This terrace is presently not well dated and must be older than the overlying age of $2565 \pm 50 \mathrm{BP}(\mathrm{A}-7948)$ or $802-543 \mathrm{cal} \mathrm{BCE}(1 \sigma)$.

\section{CONCLUSIONS}

Holocene millennial scale variations in the hydrologic balance of the Dead Sea catchment are observed through several independent records of the region suggesting a common climatic control over the east Mediterranean. Most ${ }^{14} \mathrm{C}$ ages are derived from high level cave passages and high lake 
stands represented by clay and silt beds that in places bound the ages of buried shore deposits. These higher stands most likely indicate higher precipitation/evaporation ratio over the east Mediterranean climate region (Table 1).

Table 1 Periods with higher stands of the Dead Sea level related to high precipitation/evaporation ratio. Estimations of Dead Sea levels and ages are derived from the correlation of several records discussed in the text. Age ranges are rounded to the nearest $100 \mathrm{yr}$ and calibrated according to Stuiver et al. (1998). MSL-Mediterranean Sea Level

Approximate maximum level of the Dead Sea (m below MSL)

Period ${ }^{14} \mathrm{C}$ BP

$9200-7000$

$-370 \quad 5200-4200$

$-385 \quad 3100-2600$

$-390 \quad 2100-1700$

$-392$

$60-0$

Calibrated age range

8300-6000 BCE
$4000-2900$ BCE
1400-800 BCE
100 BCE-300 BCE
$1890-1950$ BCE

The ${ }^{14} \mathrm{C}$-based chronology allows regional correlations with a wide range of disciplines, including paleobotany, archaeology, and history. When it will be more precise, the chronology will allow correlation with global Holocene paleoclimatic patterns that control the regional paleohydrology and therefore the environmental change.

The regional paleoclimatic chronology from the studied level indicators can help evaluate cultural changes in the past and predict future impacts of climatic changes.

The ${ }^{14} \mathrm{C}$-based correlation is also useful for measurement of the Mount Sedom diapir mean rising rate. This appears to be less than $10 \mathrm{~mm} / \mathrm{yr}$. Further study of the available records and the systematic collection of more ${ }^{14} \mathrm{C}$ ages is indispensable for fine-tuning of the above conclusions.

\section{ACKNOWLEDGMENTS}

The Israel Cave Research Center team participated in the field study of Mount Sedom caves. Prof Dan Bowman and Dr Hendrik Bruins improved the paper considerably with their suggestions. Support for constructing the Darga chronology was provided by the Israel Science Foundation and the Israel Ministry of Infrastructure.

\section{REFERENCES}

Anati DA, Stiller M, Shasha S, Gat JR. 1987. The thermohaline structure of the Dead Sea: 1979-1984. Earth and Planetary Science Letters 84:109-121.

Anati DA, Gavrieli I, Oren A. 1995. The residual effect of the 1991-93 rainy winter on the Dead Sea stratification. Israel Journal of Earth Sciences 44:63-70.

Bartov Y, Stein A, Enzel Y, Agnon A, Reches Z. In press. Lake levels and sequence stratigraphy of Lake Lisan, the Late Pleistocene precursor of the Dead Sea. Quaternary Research.

Begin ZB, Broecker W, Buchbinder B, Druckman Y, Kaufman A, Magaritz M, Neev D. 1985. Dead Sea and Lake Lisan levels in the last 30,000 years. Jerusalem: Geological Survey of Israel, report 29/85. 18 p.

Ben-Avraham Z, Niemi TM, Heim C, Negendank J, Nur
A. 1999. Holocene stratigraphy of the Dead Sea: Correlation of high-resolution seismic reflection profiles to sediment cores. Journal of Geophysical Research 104(B8): 17,617-25.

BenDavid-Novak H. 1998. Modern and Holocene debris flows along the western escarpment of the Dead Sea [M.Sc. thesis]. Hebrew University. 129 p.

Bowman D, Banet-Davidovich D, Bruins HJ, Van der Plicht J. 2000. Dead Sea shoreline facies with seismically-induced soft-sediment deformation structures, Israel. Israel Journal of Earth Sciences 49:4.

Bowman D, Bruins HJ, van der Plicht J. 2001. Load structure seismites in the Dead Sea area (Israel): Chronological benchmarking with ${ }^{14} \mathrm{C}$ dating. Radiocarbon. This issue. 
Bull WB. 1991. Geomorphic responses to climatic change. New York: Oxford. $326 \mathrm{p}$.

Butzer KW, Issac GL. 1972. Radiocarbon dating of East African lake levels. Science 175(4027):1069-76.

Druckman Y, Magaritz M, Sneh A. 1987. The shrinking of Lake Lisan, as reflected by the diagenesis of its marginal oolitic deposits. Israel Journal of Earth Sciences 36:101-6.

Elazari-Volcani B. 1943. Bacteria in the bottom sediments of the Dead Sea. Nature 152:274-5.

Enzel Y, Kadan G, Eyal Y. 2000. Holocene earthquakes inferred from a fan-delta sequence in the Dead Sea graben. Quaternary Research 53:34-48.

Frumkin A. 1992. The karst system of the Mount Sedom salt diapir. PhD thesis (in Hebrew, English abstract), The Hebrew University. $210 \mathrm{p}$.

Frumkin A. 1996a. Determining the exposure age of a karst landscape. Quaternary Research 46:99-106.

Frumkin A. 1996b. Uplift rate relative to base level of a salt diapir (Dead Sea, Israel), as indicated by cave levels. In: Alsop I, Blundell D, Davison I, editors. Salt Tectonics, Special Publication no. 100. London: Geological Society. p 41-7.

Frumkin A. 1997. The Holocene history of the Dead Sea levels. In: Niemi TM, Ben-Avraham Z, Gat Y, editors. The Dead Sea-the lake and its setting. Oxford: Oxford University Press. p 237-48.

Frumkin A. 2001. The Cave of the Letters sedimentsindication of an early phase of the Dead Sea depression? Journal of Geology 109(1):79-90.

Frumkin A, Magaritz M, Carmi I, Zak I. 1991. The Holocene climatic record of the salt caves of Mount Sedom, Israel. The Holocene 1(3):191-200.

Frumkin A, Carmi I, Zak I, Magaritz M. 1994. Middle Holocene environmental change determined from the salt caves of Mount Sedom, Israel. In: Bar-Yosef O, Kra R, editors. Late Quaternary Chronology and Paleoclimates of the Eastern Mediterranean. Tucson: The University of Arizona. p 315-22.

Frumkin A, Greenbaum N, Schick AP. 1998. Paleohydrology of the northern Negev: comparative evaluation of two catchments. In: Brown N, Issar A, editors. Water, environment, and society in times of climatic change, Amsterdam: Kluwer. p 97-111.

Gavrieli I. 1997. Halite deposition from the Dead Sea: 1960-1993. In The Dead Sea - the lake and its setting, edited by Niemi TM, Ben-Avraham Z, Gat Y. Oxford: Oxford University Press. p 161-70.

Goodfriend GA, Magaritz M, Carmi I. 1986. A high stand of the Dead Sea at the end of the Neolithic period: paleoclimatic and archeological inplications: Climatic Changes 9:349-56.

Greenbaum N, Schick AP, Baker VR. 2000. The paleoflood record of a hyperarid catchment, Nahal Zin, $\mathrm{Ne}-$ gev Desert, Israel. Earth Surface Processes and Landforms 25 (9):951-71.

Heim C, Leroy S, Negendank JFW. 1997. Near East de- sertification-evidence from the Dead Sea. Naturwissenschaften 84:398-401.

Kadan G. 1997. Evidence of Dead-Sea level fluctuations and neotectonic events in the Holocene fan-delta of Nahal Darga. M.Sc., Ben Gurion University of the Negev. 54 p.

Kahana R. 1999. Synoptic hydroclimatology of major floods in the Negev and Arava, southern Israel. M.Sc., The Hebrew University. 78 p.

Ken-Tor R, Stein M, Enzel Y, Marco S, Agnon A, Negendank JFW. 1998. Late Holocene earthquakes recorded by lake sediments, Ze'elim Plain, Dead Sea. Paper read at Israel Geological Society Annual Meeting at Mitzpe Ramon. 53 p.

Ken-Tor R, Stein M, Enzel Y, Marco S, Marco S, Negendank JFW. 2001. Precision of calibrated radiocarbon ages of historic earthquakes in the Dead Sea basin. $R a$ diocarbon. This issue.

Klein C. 1965. On the fluctuations of the level of the Dead Sea since the beginning of the 19th century. Jerusalem: Israel Hydrological Service, Hydrological paper no. 7. Revised edition. $83 \mathrm{p}$.

Klein C. 1982. Morphological evidence of lake level changes, western shore of the Dead Sea. Israel Journal of Earth Sciences 31:67-94.

Kudrass G, Erlenkeuser H, Vollbrecht R, Weiss W. 1991. Global nature of the Younger Dryas cooling event inferred from oxygen isotope data from Sulu Sea cores. Nature 349:406-9.

Machlus M, Enzel Y, Goldstein SL, Marco S. 2000. Reconstructing low levels of Lake Lisan by correlating fan-delta and lacustrine deposits. Quaternary International 73/74:137-44.

Manspeizer W. 1985. The Dead Sea Rift: impact of climate and tectonism on Pleistocene and Holocene sediments. In: Biddle KT, Christie-Black N, editors. Strike-slip deformation, basin formation and sedimentation. Society for Economic Paleontology and Mineralogy, Special Publication:143-58.

McClure HA. 1976. Radiocarbon chronology of Late Quaternary lakes in the Arabian Desert. Nature 263: 755-6.

Migowski C, Ken-Tor R, Negendank JFW, Stein M, Mingram J. 1998. Post-Lisan record documented in sediment sequences from the western shore area and the central basin of the Dead Sea. Terra Nostra 98(6): $100-2$.

Neev D, Emery KO. 1967. The Dead Sea, depositional processes and environments of evaporites. Geological Survey of Israel Bulletin 41:1-147.

Neev D, Emery KO. 1995. The destruction of Sedom, Gomorrah, and Jericho. Oxford: Oxford University Press. $175 \mathrm{p}$.

Otvos EG. 2000. Beach ridges-definitions and significance. Geomorphology 32:83-108.

Roberts N. 1982. Lake levels as an indicator of Near Eastern palaeo-climates: a preliminary appraisal. In: 
Bintliff JL, Van Zeist W, editors. Palaeoclimates, palaeoenvironments and human communities in the eastern Mediterranean region in later prehistory. Oxford, BAR International Series I33(i):235-71.

Roberts N, Taieb M, Barker P, Damnati B, Icole M, Williamson D. 1993. Timing of the Younger Dryas event in East Africa from lake-level changes. Nature 366: $146-8$.

Street FA. Grove AT. 1979. Global maps of lake level fluctuations since 30,000 yr BP. Quaternary Research 12:83-118.

Taylor KC, Mayewski PA, Alley RB, Brook EJ, Gow AG, Grootes PM, Meese DA, Salzman ES, Severinghaus JP, Twickler MS, White JWC, S. W, Zielinski GA. 1997. The Holocene - Younger Dryas transition recorded at Summit, Greenland. Science 278:825-7.

Schramm A, Stein M, Goldstein SL. 2000. Calibration of the ${ }^{14} \mathrm{C}$ time-scale to $>40 \mathrm{ka}$ by ${ }^{234} \mathrm{U}-{ }^{230} \mathrm{Th}$ dating of Lake Lisan sediments (last glacial Dead Sea). Earth and Planetary Science Letters 175(1-2):27-40.

Steinhorn I, Assaf G, Gat J, Nishr YA, Nissenbaum A, Stiller M, Beyth M, Neev D, Garber R, G. F, Weiss W. 1979. The Dead Sea: Deepening of the mixolimnion signifies the overture to overturn the water column. Science 206:55-6.

Stiller M, Carmi I, Kaufman A. 1988. Organic and inorganic ${ }^{14} \mathrm{C}$ concentrations in the sediments of Lake Kinneret and the Dead Sea (Israel) and the factors which control them. Chemical Geology 73:63-78.

Stiller M, Chung YC. 1984. Radium in the Dead Sea: a possible tracer for the duration of meromixis. Limnology and Oceanography 29(3):574-86.

Stiller M, Gat JR, Kaushansky P. 1997. Halite precipitation and sediment deposition as measured in sediment traps deployed in the Dead Sea: 1981-1983. In: Niemi TM, Ben-Avraham Z, Gat Y, editors. The Dead Seathe lake and its setting. Oxford: Oxford University Press. p 171-83.

Stuiver M, Reimer PJ, Bard E, Beck JW, Burr GS, Hughen KA, Kromer BGM, van der Plicht J, Spurk M. 1998. INTCAL98 radiocarbon age calibration, 24,000-0 cal BP. Radiocarbon 40(3):1041-83.

Talma AS, Vogel JC, Stiller M. 1997. The radiocarbon content of the Dead Sea. In: Niemi TM, Ben-Avraham $\mathrm{Z}$, Gat Y, editors. The Dead Sea-the lake and its setting, Oxford: Oxford University Press. p 193-98.

Yechieli Y. 2000. Hever 1 borehole - geological and hydrological finds (in Hebrew). Jerusalem: Geological Survey of Israel, Report 29/2000. 14p.

Yechieli Y, Magaritz M, Levy Y, Weber U, Kafri U, Woelfli W, Bonani G. 1993. Late Quaternary geological history of the Dead Sea area, Israel. Quaternary Research 39:59-67.

Zak I. 1967. The geology of Mount Sedom [PhD thesis]. The Hebrew University. 208 p. In Hebrew with English abstract. 